Journal of Clinical Investigation

Vol. 42, No. 2, 1963

\title{
OBSERVATIONS CONCERNING THE BINDING OF THYROID HORMONES BY HUMAN SERUM PREALBUMIN *
}

\author{
By SIDNEY H. INGBAR $†$ \\ (From the Thorndike Memorial Laboratory, Second and Fourth [Harvard] Medical Services, \\ Boston City Hospital, and the Department of Medicine, Harvard Medical School, \\ Boston, Mass.)
}

(Submitted for publication July 6, 1962; accepted October 10, 1962)

There is general agreement that thyroxine $\left(\mathrm{T}_{4}\right)^{1}$ is the major component of the thyroid hormone in blood, where it exists almost entirely in a dissociable complex with certain plasma proteins. From the numerous studies that followed the discovery of the $\mathrm{T}_{4}$-binding $(\alpha)$-globulin of plasma (TBG) in 1952, it first appeared that the binding of $\mathrm{T}_{4}$ in plasma could be mainly ascribed to binding sites of high avidity but low concentration, contributed by TBG. A secondary role was ascribed to binding sites of low avidity but almost unlimited concentration, contributed by albumin. These conclusions, based almost entirely on data obtained by electrophoretic separation of serum or plasma proteins on filter paper in barbital buffer at $\mathrm{pH}$ 8.6 , have been considered in several recent reviews $(1,2)$.

In 1956, during efforts to purify TBG, an additional $\mathrm{T}_{4}$-binding protein was observed in subfractions of human plasma proteins. Subsequent experiments revealed that a $\mathrm{T}_{4}$-binding protein of similar electrophoretic mobility could be consistently demonstrated in unfractionated normal human serum when electrophoretic separations were performed in a buffer containing tris(hydroxymethyl)aminomethane (Tris) and maleic acid, rather than barbital. Because of its rapid anodal migration at $\mathrm{pH} 8.6$, this protein was termed the thyroxine-binding prealbumin (TBPA) (3). It avidly bound $\mathrm{T}_{4}$, but failed to bind significant quantities of $3,5,3^{\prime}$-triiodothyronine $\left(\mathrm{T}_{3}\right)$. It was sug-

* Investigation supported in part by research grant A-267 from the National Institute of Arthritis and Metabolic Diseases, Bethesda, Md., and in part by the Medical Research and Development Board, Office of the Surgeon General, Department of the Army, under contract DA49-007.

† Investigator, Howard Hughes Medical Institute.

1 Unless otherwise indicated, wherever reference is made to optically active compounds, the levorotatory isomer is meant. gested that TBPA is a protein distinct from TBG, with which it might share a significant role in the transport of $\mathrm{T}_{4}$. Although several subsequent reports have suggested the contrary, the present report will describe in detail data indicating that TBPA is native to plasma, is distinct from TBG, and participates in the transport of $T_{4}$ under physiologic conditions. ${ }^{2}$

\section{METHODS AND RESULTS}

A previous communication has fully described the Tris-maleate buffer and electrophoretic apparatus employed in the present studies, as well as the techniques used in storing $\mathrm{I}^{131}$-labeled compounds, in determining their distribution after electrophoresis, and in calculating hormonal binding capacities of TBG and TBPA from filter paper electrophoretic analysis of serum or plasma fractions (6). Unless significantly modified, detailed descriptions of these techniques will not be included here.

Interrelations of TBG and TBPA in plasma fractions. Lyophilized fractions of plasma proteins ${ }^{3}$ prepared by Method 6 of Cohn and his colleagues (7) were dissolved in isotonic $\mathrm{NaCl}$. After removal of insoluble residue by centrifugation, protein concentrations in the supernatant fluids were determined by the biuret reaction (8) and solutions were adjusted with physiological saline to a concentration of $3.0 \mathrm{~g}$ protein per 100 ml. I ${ }^{131}$-labeled $T_{4}$ was added to each solution to a final concentration of $2 \mu \mathrm{c}$ per $\mathrm{ml}$ (approximately $4 \mu \mathrm{g} \mathrm{T}_{4}$ per $100 \mathrm{ml}$ ). One sample of each solu-

2 Certain of the data presented herein have been described before meetings of the New York Academy of Sciences and the Laurentian Hormone Conference, and have been briefly referred to in the published transactions of these organizations $(4,5)$.

${ }^{3}$ Kindly supplied by Dr. Robert Pennell, Protein Foundation, Jamaica Plain, Mass. 


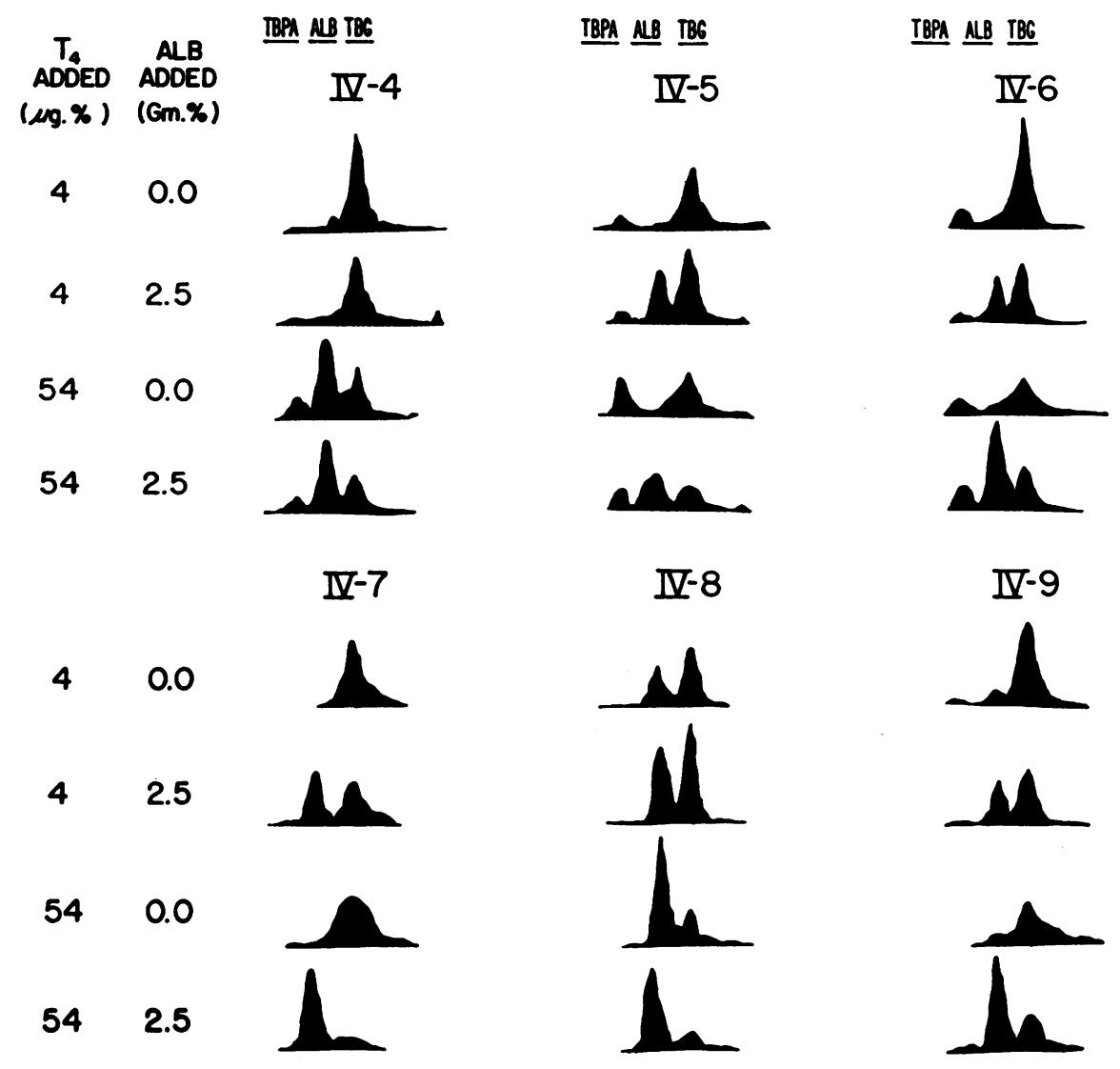

Fig. 1. Binding of $I^{131}$-LABELEd thyroxine in Cohn fractions of plasma during FILTER PAPER eleCtrophoresis IN Tris-maleate buffer, PH 8.6. Dark areas represent radioactive scans of individual electrophoretograms.

tion was left unaltered, while others were enriched with either $3.0 \mathrm{~g}$ per $100 \mathrm{ml}$ of dried human serum albumin (HSA), or $150 \mu \mathrm{g}$ per $100 \mathrm{ml}$ of stable $\mathrm{T}_{4}$, or both. ${ }^{4}$ The resulting samples of each plasma fraction were then subjected to electrophoresis in Whatman no. 3 filter paper with Tris-maleate buffer at $\mathrm{pH}$ 8.6. This technique afforded a semiquantitative assessment of the binding activity of TBPA in each of the plasma fractions tested. Samples containing high concentrations of stable $\mathrm{T}_{4}$ made possible demonstration of hormonal binding to TBPA in fractions rich in TBG and poor in TBPA. In fractions poor in TBG, HSA provided a binding protein with which TBPA could compete. Results are depicted in Figure 1. TBG was present to a variable extent in all fractions tested. TBPA, however, could

4 The albumin employed in this experiment, Fraction V of Cohn and his colleagues (7), was shown by electrophoresis to contain a trace of TBG, but no TBPA. be demonstrated only in Fractions IV-4, IV-5, IV -6 , and to a very slight extent, in Fraction IV-9.5

Plasma Fraction IV-4 (7) was further refined by precipitation with ammonium sulfate, followed by adsorption on and elution from diethylaminoethyl(DEAE)-cellulose (acetate cycle). These procedures employed in purifying TBG and TBPA, to be described in detail in a later communication, yielded a "resin eluate" fraction highly enriched in these proteins and free of albumin. TBG and TBPA were enriched with $\mathrm{I}^{131}$. labeled $\mathrm{T}_{4}$ and were separated from each other by zonal electrophoresis of resin eluates in cellulose columns (9), with either Tris-maleate or $0.06 \mathrm{M}$ barbital buffer at $\mathrm{pH}$ 8.6. After electrophoresis, proteins were eluted by passing through the col-

\footnotetext{
${ }^{5}$ Variation in the relative proportion of $T B G$ and TBPA was encountered in other batches of the fractions tested.
} 
umns a buffer similar to that employed during electrophoresis. Samples were collected into a fraction collector, and individual fractions were assayed for radioactivity and for concentration of protein by direct well-counting and by determination of optical density at $280 \mathrm{~m} \mu$, respectively.

When equal samples of the same resin eluate were studied in this manner, approximately equal quantities of a protein migrating more rapidly than albumin were eluted from the column, regardless of the buffer system employed during electrophoresis. Fractions containing prealbumin also contained appreciable radioactivity when prepared in barbital buffer; however, considerably more radioactivity was associated with prealbumin (and correspondingly less with TBG) when Trismaleate buffer was used (Figure 2).

Central fractions from the prealbumin and TBG peaks were separately pooled and subjected to pressure dialysis at 25 inches of $\mathrm{Hg}$ and $4^{\circ} \mathrm{C}$ for 72 hours against 3 changes of 200 to 500 volumes of distilled water. Filter paper electrophoresis with barbital buffer at $\mathrm{pH} 8.6$ of samples of the two concentrated pools revealed only prealbumin, in one case, and TBG plus variably small proportions, estimated to be from 10 to 30 per cent, of $\alpha_{1^{-}}$and $\alpha_{2}$-globulins, in the other. In addition, subsequent analyses indicated that prealbumin prepared in this manner was homogeneous during

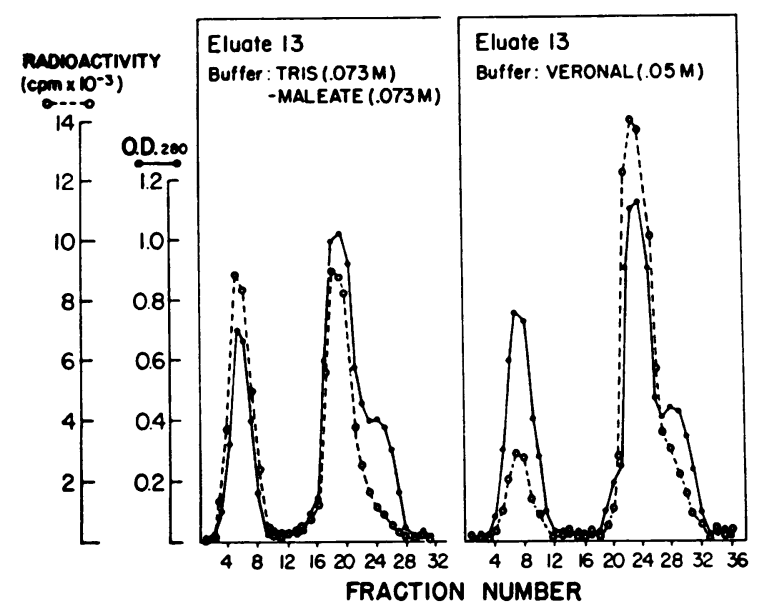

Fig. 2. Cellulose colum electrophoresis of $\mathrm{I}^{131}$ LABELED THYROXINE IN SOLUTIONS OF HUMAN PLASMA FRACTIONS RICH IN PREALBUMIN AND THYROXINE-BINDING GLOBULIN (TBG) : EFFECT OF BUFFER MEDIUM, PH 8.6. The first radioactive peak eluted represents prealbumin and the second TBG. Veronal = barbital. both free electrophoresis and ultracentrifugation. Little or no loss of radioactivity (0 to 12 per cent) occurred from either the TBG or the prealbumin pools during dialysis, regardless of whether Trismaleate or barbital buffers had been employed in their preparation. Ascending filter-paper chromatography (butanol-dioxane-2N-ammonia, $4: 1$ : 5 ) of butanol extracts of these concentrated fractions revealed that the ${ }^{131}$-labeled material associated with them was still $\mathrm{T}_{4}$.

Fractions rich in TBG were prepared from resin eluates by column electrophoresis in barbital buffer and were subjected to re-electrophoresis in either filter paper sheets or cellulose columns, with Tris-maleate buffer. In neither supporting medium did detectable quantities of added radioactive $T_{4}$ or of protein appear in the prealbumin zone.

Effects of buffer ions on TBPA. As previously reported (3), binding of labeled $\mathrm{T}_{4}$ by TBPA could regularly be demonstrated when normal human serum was subjected to electrophoresis in filter paper with Tris-maleate buffer at $\mathrm{pH}$ 8.6. In order to evaluate the possible effects on binding of varying concentrations of these buffer ions, $T_{4}-$ binding capacities of TBG and TBPA were determined in the sera of 4 normal subjects and 4 patients with inflammatory disease. In the latter patients, the $\mathrm{T}_{4}$-binding capacity of TBPA was subnormal when assessed by electrophoresis in standard Tris-maleate buffer. Comparative studies were performed in Tris-maleate buffer at onefourth, one-half, and twice the usual, as well as at the usual, concentration. Variations in the concentration of Tris-maleate had no consistent effect on the $\mathrm{T}_{4}$-binding capacity of TBPA (Figure 3 ). A tendency in some sera toward lower values for the binding capacity of TBPA at lower concentrations of buffer may have been related to the less adequate separation of TBPA from albumin that occasionally occurred in the more dilute buffer media.

In order to ascertain whether the Tris-maleate buffer system was necessary for demonstration of TBPA in serum (as opposed to plasma fractions where $\mathrm{T}_{4}$-binding by prealbumin in a barbital buffer had already been found), samples of normal human serum, enriched with I ${ }^{131}$-labeled and stable $T_{4}$, were subjected to filter paper electrophoresis in the following solutions, all at $\mathrm{pH} 8.4$ 


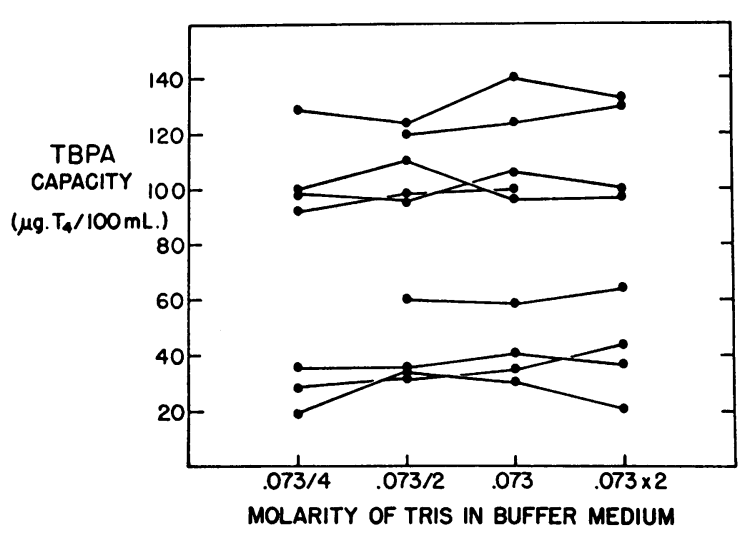

Fig. 3. Binding CAPACITY OF THYROXINE-BINDING PREALBUMiN (TBPA) IN VARYING CONCENTRATIONS OF Tris-maleate BUfFer, $\mathrm{PH}$ 8.6. Sera obtained from 4 normal subjects and 4 with acute inflammatory disease. Molarity of maleate equal to the molarity of Tris.

to 8.6: $0.06 \mathrm{M}$ sodium phosphate, $0.05 \mathrm{M}$ ammonium carbonate, $0.05 \mathrm{M}$ alanine- $0.05 \mathrm{M} \mathrm{KCl}$, and $0.05 \mathrm{M}$ glycine- $0.05 \mathrm{M} \mathrm{KCl}$. Clearly defined zones of migration of $\mathrm{T}_{4}$, coinciding with those of TBPA as observed in the Tris-maleate system, were evident in each of the solutions employed. Sufficient observations to permit a quantitative comparison of the $\mathrm{T}_{4}$-binding capacities of TBPA in the several systems were not made.

Dialysis systems were also employed to assess the effects of varying buffer anions upon $\mathrm{T}_{4}$-binding by TBPA. Samples of serum were obtained from patients with hepatic cirrhosis. Sera selected for use were first shown to have a markedly decreased $\mathrm{T}_{4}$-binding capacity of TBPA, as assessed in the Tris-maleate buffer system. Sera were then dialyzed for 24 hours against 100 volumes of the following solutions: $0.06 \mathrm{M}$ phosphate, $0.073 \mathrm{M}$ Tris-0.073 M maleate, $0.146 \mathrm{M}$ Tris$0.146 \mathrm{M}$ maleate, $0.05 \mathrm{M}$ alanine- $0.05 \mathrm{M} \mathrm{KCl}$, $0.05 \mathrm{M}$ glycine- $0.05 \mathrm{M} \mathrm{KCl}$, and $0.05 \mathrm{M}$ ammonium carbonate, $\mathrm{pH} 8.4$ to 8.6. After dialysis, protein concentrations were measured by the biuret reaction, and the total protein in each sample was adjusted with the appropriate buffer to a final concentration of $4.5 \mathrm{~g}$ per $100 \mathrm{ml}$. Purified prealbumin was dissolved in isotonic saline to a concentration of $3.0 \mathrm{~g}$ per $100 \mathrm{ml}$. $\mathrm{I}^{131}$-labeled $\mathrm{T}_{4}(100 \mu \mathrm{c}$ per $\mathrm{ml})$ was added, and samples were then diluted with each of the foregoing buffers to a final concentration of $50 \mathrm{mg}$ per $100 \mathrm{ml}$. Two-ml samples of the solutions of pre- albumin were then dialyzed against $12 \mathrm{ml}$ of serum equilibrated with the corresponding buffer. Half$\mathrm{ml}$ samples of the serum phase were withdrawn at regular intervals for 48 hours, were subjected to precipitation and washing with 10 per cent trichloroacetic acid (TCA), and the rate of increase of precipitable radioactivity in the dialyzed fraction was calculated for each buffer system. With the rate of dialysis of precipitable radioactivity in phosphate buffer as a reference $(0.032$ per cent per 24 hours), the following values for each of the solutions were obtained (mean of 2 experiments) : phosphate, $1.00 ; 0.073 \mathrm{M}$ Tris- 0.073 $\mathrm{M}$ maleate, $0.91 ; 0.146 \mathrm{M}$ Tris- $0.146 \mathrm{M}$ maleate, 0.89 ; alanine, 1.08 ; glycine, 1.02 ; ammonium carbonate, 0.96 . Differences in dialysis rates of similar small degree were noted when HSA (4.5 $\mathrm{g}$ per $100 \mathrm{ml}$ ), rather than serum, was employed outside of the dialysis sac.

Binding of other iodophenols. Preparations of $\mathrm{I}^{131}$-labeled tri- and tetraiodothyroacetic $\left(\mathrm{TA}_{3}\right.$ and $\left.\mathrm{TA}_{4}\right)$ and tri- and tetraiodothyropropionic acids $\left(\mathrm{TP}_{3}\right.$ and $\left.\mathrm{TP}_{4}\right)$, as well as $\mathrm{D}$-thyroxine (D- $\left.\mathrm{T}_{4}\right)$, were diluted in 1 per cent HSA to a concentration of $160 \mu \mathrm{c}$ per $\mathrm{ml}$ immediately upon arrival from a commercial source. ${ }^{6}$ Single or pooled specimens of serum obtained from normal volunteers were enriched with labeled iodophenol together with increasing, equimolecular concentrations of the corresponding unlabeled compound. ${ }^{7}$ Filter paper electrophoresis of specimens was performed, with standard Tris-maleate buffer, and the binding capacities of TBG and TBPA for each of the compounds tested were determined. In most instances, binding capacities of TBG and TBPA for $\mathrm{L}^{-\mathrm{T}_{4}}$ were assessed concomitantly in other samples of the same serum.

$\mathrm{D}-\mathrm{T}_{4}$ was bound little if at all by TBPA and was associated mainly with TBG and secondarily with albumin. Results obtained with different batches of $\mathrm{I}^{131}$-labeled $\mathrm{D}-\mathrm{T}_{4}$ varied slightly, perhaps from contamination of $\mathrm{D}-\mathrm{T}_{+}$with small amounts of $\mathrm{L}-\mathrm{T}_{4}$. In some batches, no binding of $\mathrm{D}-\mathrm{T}_{4}$ to TBPA could be discerned, even at the lowest concentrations employed $(0.2 \mu \mathrm{c}$ per $\mathrm{ml}$, approximately $0.4 \mu \mathrm{g} \mathrm{D}-\mathrm{T}_{+}$per $100 \mathrm{ml}$ ). In other

${ }^{6}$ Obtained in 50 per cent propylene glycol solution from Abbott Laboratories, Oak Ridge, Tenn.

${ }^{7}$ Kindly supplied by Dr. Wayne L. Ruddy, WarnerChilcott Laboratories, Morris Plain, N. J. 
batches, a small proportion of $\mathrm{I}^{131}$-labeled $\mathrm{D}-\mathrm{T}_{4}$ was associated with TBPA. In these instances, labeled $\mathrm{D}-\mathrm{T}_{4}$ was displaced from TBPA by the addition of stable $\mathrm{L}-\mathrm{T}_{4}$ far more readily than was labeled L- $\mathrm{T}_{4}$ itself (Figure 4). $\mathrm{I}^{131}$-labeled D- $\mathrm{T}_{4}$ was displaced from TBG onto albumin by the addition to serum of stable $\mathrm{L}-\mathrm{T}_{4}$. At all concentrations of stable $\mathrm{L}-\mathrm{T}_{4}$ employed, however, a slightly greater percentage of labeled $\mathrm{D}-\mathrm{T}_{4}$ than of $\mathrm{L}^{-\mathrm{T}_{4}}$ was associated with TBG in paired samples of the same serum. Studies of the effects of enriching sera with stable $\mathrm{D}-\mathrm{T}_{4}$ upon the binding of $\mathrm{I}^{131}$ labeled $\mathrm{L}$ - and $\mathrm{D}-\mathrm{T}_{4}$ were not performed.

Low concentrations of $\mathrm{I}^{131}$-labeled $\mathrm{TA}_{4}$ and $\mathrm{TP}_{4}(0.4 \mu \mathrm{g}$ per $100 \mathrm{ml}$ and $4.0 \mu \mathrm{g}$ per $100 \mathrm{ml}$, or approximately $5 \times 10^{-3}$ and $5 \times 10^{-2} \mu$ moles per liter, respectively) were bound almost completely to TBPA during electrophoresis at $\mathrm{pH} 8.6$ in Tris-maleate buffer. When increasing concentrations of the corresponding stable compounds were added, labeled material was progressively displaced onto albumin. Binding to TBG was not evident. The binding capacity of TBPA for $\mathrm{TA}_{4}$ and $\mathrm{TP}_{4}$ in several normal sera ranged between approximately 190 and $210 \mu \mathrm{g}$ per $100 \mathrm{ml}(2.5$ and $2.8 \mu$ moles per liter) and on a molar basis, consistently exceeded by 40 to 50 per cent the molar binding capacity of TBPA for $\mathrm{T}_{4}$, measured concomitantly in the same sera (approxi-

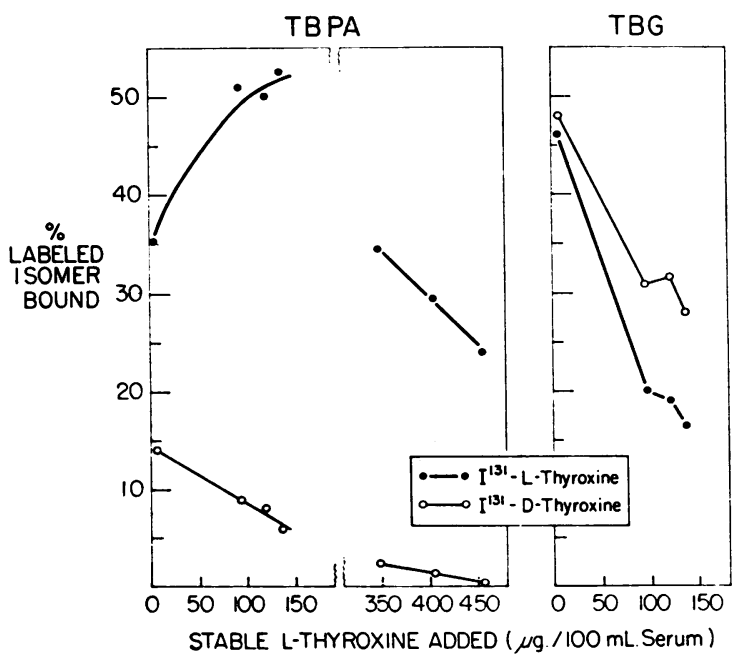

Fig. 4. BINdiNg OF $I^{131}$-LABELED D- AND L-THYROXINE TO TBPA AND TBG DURING FILTER PAPER ELECTROPHORESIS OF NORMAL HCMAN SERUM IN TRIS-MALEATE BUFFER, $\mathrm{PH}$ 8.6. EFFECT OF ADDING VARYING CONCENTRATIONS OF STABLE L-THYROXINE.

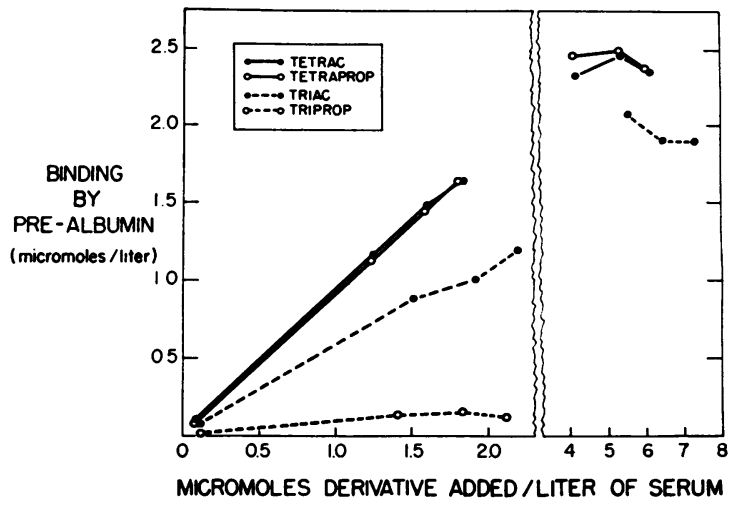

Fig. 5. Binding capacity of TBPA IN NORMal hUMAN SERUM FOR SEVERAL DEAMINATED DERIVATIVES OF THYROXINE AND 3,5,3'-L-TRIIODOTHYRONINE. Electrophoresis of serum in Tris-maleate buffer, $\mathrm{pH}$ 8.6. Binding capacity for thyroxine in the same serum was $1.8 \mu$ moles per liter $(139 \mu \mathrm{g}$ per $100 \mathrm{ml})$. Molecular weights : thyroxine, 777 ; tetraiodothyroacetic acid, 748 ; tetraiodothyropropionic acid, 762; triiodothyroacetic acid, 622; and triiodothyropropionic acid, 636.

mately $1.8 \mu$ moles per liter, or $140 \mu \mathrm{g}$ per $100 \mathrm{ml}$ ) (Figure 5).

Low concentrations of $\mathrm{TA}_{3}$ and especially $\mathrm{TP}_{3}$ were less well bound by TBPA than their tetraiodinated analogues. At $0.4 \mu \mathrm{g}$ per $100 \mathrm{ml}$ (approximately $6 \times 10^{-3} \mu$ moles per liter), about 75 per cent of added labeled $\mathrm{TA}_{3}$ was bound by TBPA, and the remainder with albumin. The molar binding capacity of TBPA for $\mathrm{TA}_{3}$ was approximately the same as that for $T_{4}$. $T_{3}$, was only weakly bound by TBPA. At a concentration of $0.4 \mu \mathrm{g}$ per $100 \mathrm{ml}$ (approximately $6 \times 10^{-3}$ $\mu$ moles per liter), about one-fourth of the labeled compound was associated with TBPA, and the remainder with albumin. The percentage associated with TBPA declined rapidly as the concentration of stable $\mathrm{TP}_{3}$ was increased, the apparent $\mathrm{TP}_{3}$-binding capacity of TBPA being only 10 to $20 \mu \mathrm{g}$ per $100 \mathrm{ml}$ ( 0.15 or $0.31 \mu$ mole per liter $)$.

Binding of the deaminated derivatives of $T_{t}$ and $\mathrm{T}_{3}$ to TBG was not evident during scanning procedures, but a faint band of radioactivity could be seen in the TBG zone in radioautographs of the foregoing samples.

In additional experiments, sera containing $2 \mu \mathrm{c}$ per $\mathrm{ml}$ of $\mathrm{I}^{131}$-labeled $\mathrm{TA}_{4}, \mathrm{TA}_{3}, \mathrm{TP}_{4}$, or $\mathrm{TP}_{3}$ were enriched with standard concentrations of stable $\mathrm{T}_{4}$. Typical results are presented in Figure 6. $\mathrm{T}_{4}$ readily displaced $\mathrm{TP}_{3}$ from TBPA. $\mathrm{TA}_{3}$ was 


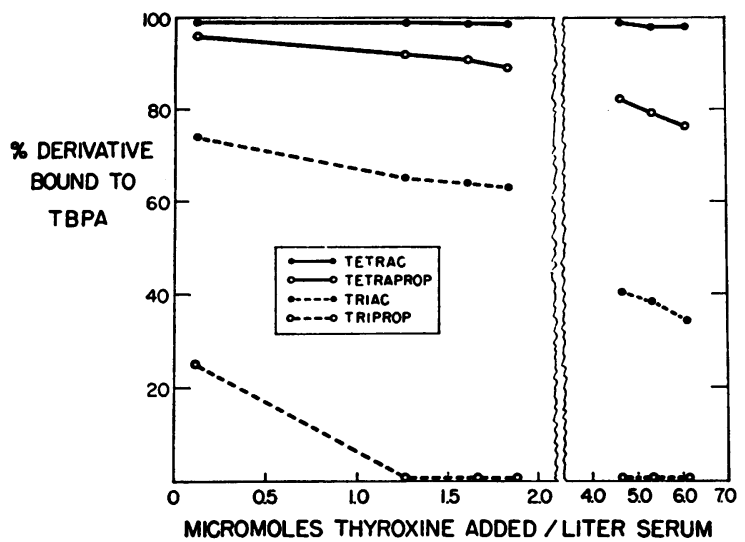

Fig. 6. Displacement of $I^{131}$-LABeled DEAMinated DERIVATIVES OF THYROXINE AND 3,5,3'-L-TRIIODOTH YRONINE FROM TBPA BY VARYING CONCENTRATIONS OF STABLE L-THYROXINE. Electrophoresis of normal human serum in Tris-maleate buffer, $\mathrm{pH}$ 8.6. Molecular weights as given for Figure 5.

less readily displaced, whereas at concentrations of added $\mathrm{T}_{4}$ ranging between 87 and $130 \mu \mathrm{g}$ per $100 \mathrm{ml}$ (approximately 1.1 to $1.7 \mu$ moles per liter), $\mathrm{TA}_{4}$ and $\mathrm{TP}_{4}$ were displaced little if at all. At higher concentrations of $\mathrm{T}_{4}$, slight displacement of labeled $\mathrm{TA}_{4}$ and $\mathrm{TP}_{4}$ from TBPA was evident, especially in the case of $\mathrm{TP}_{4}$.

The ability of standard concentrations of the deaminated derivatives of $T_{4}$ and $T_{3}$ to displace tracer quantities of labeled $\mathrm{T}_{4}$ from TBPA was compared with the ability of stable $T_{4}$ itself to effect this displacement. Electrophoretic studies were performed in samples of pooled normal serum enriched with $2.0 \mu \mathrm{c}$ per $\mathrm{ml}$ of ${ }^{131}$-labeled $\mathrm{T}_{4}$, together with increasing equimolecular concentrations of one of the derivatives or of $\mathrm{T}_{4}$ itself. The effect of stable $T_{4}$ and of the derivatives on the distribution of labeled $\mathrm{T}_{4}$ differed greatly. At concentrations sufficient to saturate $T_{4}$-binding sites on TBG but not on TBPA, stable $\mathrm{T}_{4}$ displaced labeled $\mathrm{T}_{4}$ from TBG to TBPA. Labeled $\mathrm{T}_{4}$ was displaced from TBPA only when concentrations of stable $T_{4}$ sufficient to saturate $T_{4}$ binding sites on TBPA were approached or exceeded. As judged from the distribution of labeled $T_{4}$ in control specimens containing only endogenous stable hormone, $\mathrm{TA}_{4}$ and $\mathrm{TP}_{4}$ were even more effective than $T_{4}$ itself in displacing labeled $\mathrm{T}_{4}$ from TBPA. At the two highest concentrations of derivative employed, displacement of labeled $\mathrm{T}_{4}$ from TBPA was complete (Figure
7). Labeled $\mathrm{T}_{4}$ displaced from TBPA became associated mainly with TBG, and to a far lesser extent, with albumin. This finding suggested that the deaminated derivatives did not significantly inhibit the binding of $T_{4}$ to $T B G$, and was consistent with the failure of appreciable quantities of labeled derivatives themselves to bind to TBG, as described above. Stable $\mathrm{TP}_{3}$ had no effect, and $\mathrm{TA}_{3}$ only a slight effect, in displacing labeled $\mathrm{T}_{4}$ from TBPA.

Inhibitors of $T_{4}$-binding by $T B P A$. In view of the rarity with which $\mathrm{T}_{4}$-binding by TBPA in normal serum can be demonstrated when paper electrophoresis is performed in barbital buffer, experiments were designed to determine whether barbital inhibits the binding of $T_{4}$ by this protein. Samples of normal human serum were enriched with $\mathrm{I}^{131}$-labeled and stable $\mathrm{T}_{4}$, and binding capacities for TBG and TBPA were determined in standard Tris-maleate buffer. Concomitantly, portions of the same samples were subjected to electrophoresis in Tris-maleate buffer to which had been added barbital in $0.005,0.025$, and $0.050 \mathrm{M}$ concentrations.

At the two higher concentrations of added barbital, significant quantities of I'131-labeled $\mathrm{T}_{4}$ could not be demonstrated in the TBPA zone. At the lowest concentration of barbital, binding of $T_{4}$ to TBPA was demonstrable, though decreased. In addition to its apparent inhibitory action on $\mathrm{T}_{4}$ binding by TBPA, another effect of barbital was

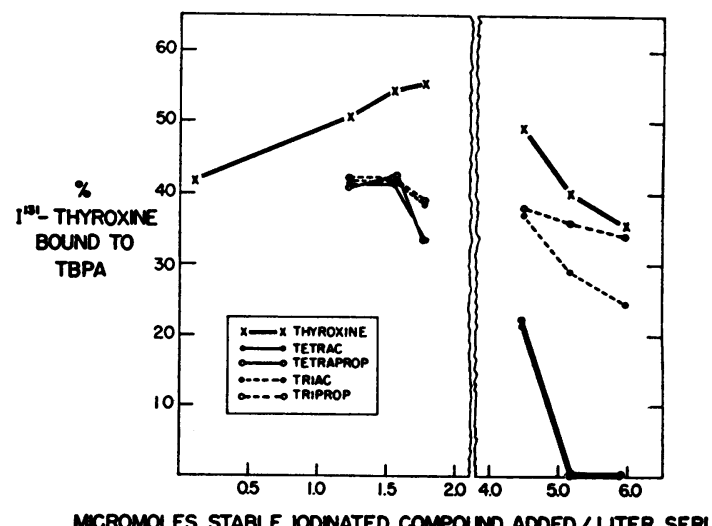

Fig. 7. Displacement of tracer concentrations of $I^{131}$-LABELED THYROXINE FROM TBPA IN NORMAL HUMAN SERUM BY ADDITION OF STABLE THYROXINE AND SEVERAL OF ITS DERIVATIVES. Electrophoresis of serum in Trismaleate buffer, $\mathrm{pH}$ 8.6. Molecular weights as given for Figure 5. 
noted. Both at the low concentration of added $\mathrm{T}_{4}$ and at concentrations sufficient to saturate TBG, i.e., at 87 to $130 \mu \mathrm{g}$ per $100 \mathrm{ml}$, inhibition of binding by TBPA was associated with an increase in the proportion of added $\mathrm{T}_{4}$ migrating in the $\alpha$-globulin zone and hence with an increase in the calculated $\mathrm{T}_{4}$-binding capacities of proteins $\mathrm{mi}$ grating in this area. Results similar to those depicted in Figure 8 were found in five additional experiments in which binding capacities of TBG and TBPA were determined after electrophoresis of normal sera in Tris-maleate buffer and in Trismaleate buffer to which $0.05 \mathrm{M}$ barbital had been added. In all, binding of $\mathrm{T}_{4}$ by TBPA was abolished, whereas the binding capacity of proteins in or near the TBG zone was increased by an average of 69 per cent.

Although it was not discernible by radioactive scanning, a fine band of radioactivity was often evident in the $\alpha_{1}$-globulin zone in radioautographs of sera subjected to electrophoresis in the Trismaleate-barbital system. The proportion of labeled $\mathrm{T}_{4}$ localized in this band was not determined. By inspection, however, it did not appear likely that this faint band of $\mathrm{T}_{4}$ could account for all of the increase that barbital induced in the binding capacity of moieties in the $\alpha$-globulin zone.
To clarify this finding further, similar studies were performed in serum virtually devoid of TBG ( $\mathrm{T}_{4}$-binding capacity less than $1 \mu \mathrm{g} \mathrm{T}_{4}$ per 100 $\mathrm{ml}$ ), but normal with respect to TBPA (6). As was the case in normal sera, addition of $0.05 \mathrm{M}$ barbital to Tris-maleate buffer obliterated $\mathrm{T}_{4}$-binding by TBPA. Only a very slight increase, however, was induced in the negligible binding of $T_{4}$ seen in control electrophoretograms in the $\alpha$-globulin zone, and most of the labeled $\mathrm{T}_{4}$ displaced from TBPA by barbital became associated with albumin.

Normal human serum, enriched with $\mathrm{I}^{131}$-labeled and varying concentrations of stable $\mathrm{TA}_{4}$, was subjected to electrophoresis both in Trismaleate and in $0.05 \mathrm{M}$ barbital buffer at $\mathrm{pH}$ 8.6. Binding of $\mathrm{TA}_{4}$ by protein migrating anodally to albumin was readily demonstrable in barbital buffer, but a smaller proportion of the $\mathrm{TA}_{4}$ was associated with TBPA than was the case in the Tris-maleate buffer control (Figure 9). Barbital did not induce binding of $\mathrm{TA}_{4}$ to proteins localized in the $\alpha$-globulin zone sufficient to be discernible by scanning procedures.

Dialysis systems afforded evidence that barbital also inhibits the binding of $\mathrm{T}_{4}$ by purified prealbumin. Two-ml samples of solutions of puri-

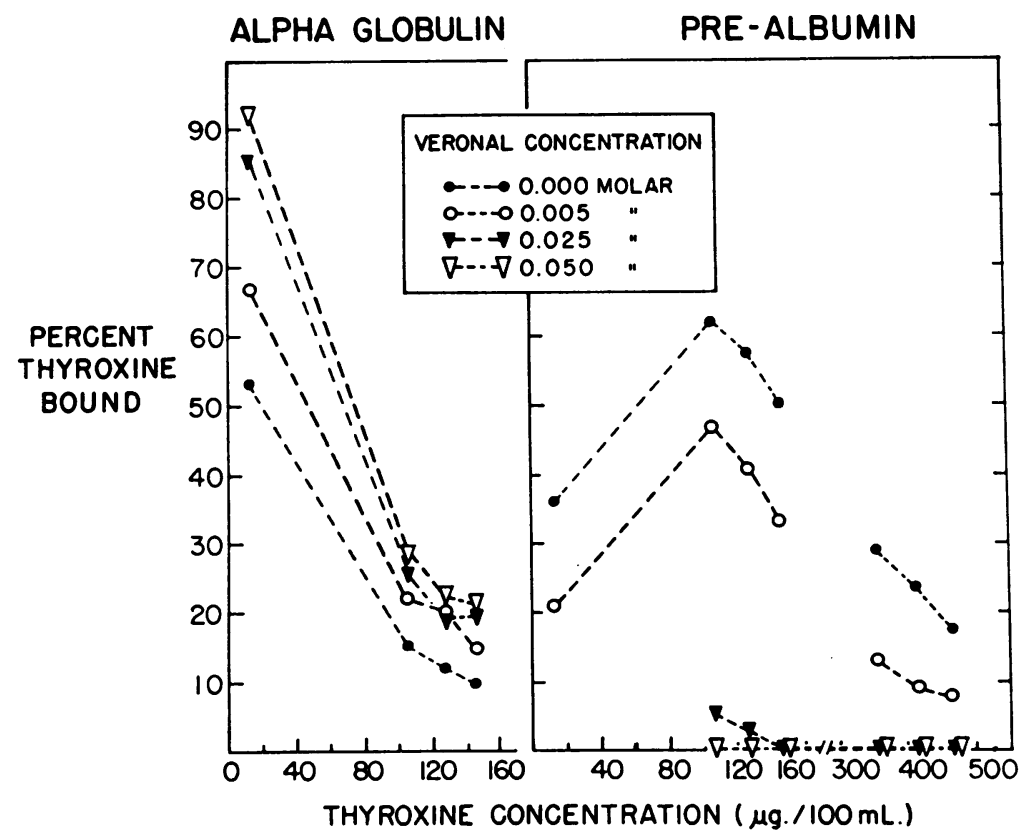

Fig. 8. The effect of adding barbital (Veronal) to Tris-maleate BUFFER, PH 8.6, ON THE BINDING OF THYROXINE IN NORMAL HUMAN SERUM. 


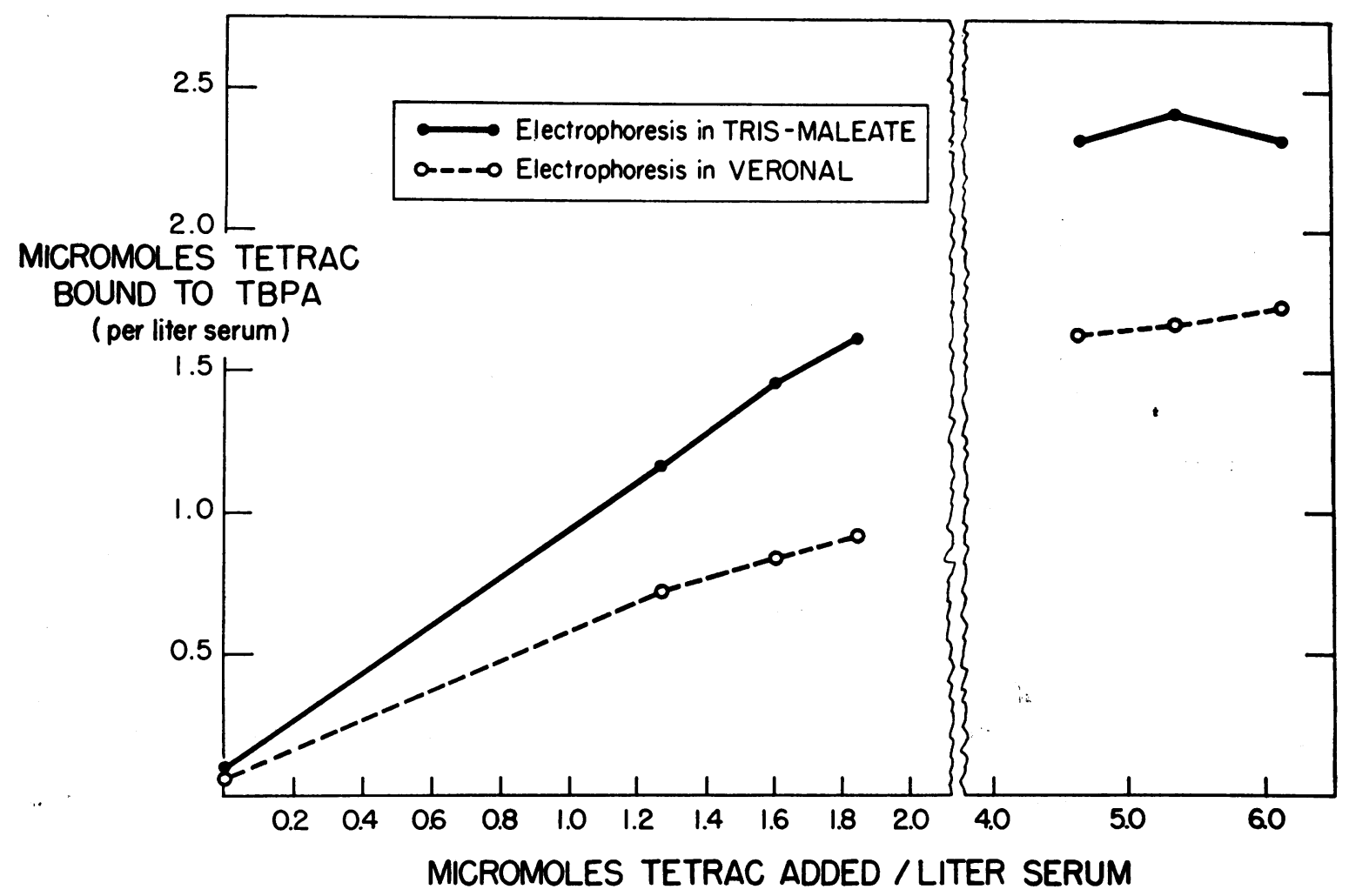

Fig. 9. DifFERENCES IN THE BINDING OF TETRAIODOTHYROACETIC ACID TO TBPA IN NORMAL HUMAN SERUM DURING electrophoresis in Tris-maleate and in barbital (Veronal) buffer, both at pH 8.6.

fied prealbumin $(25 \mathrm{mg}$ per $100 \mathrm{ml}$ ) containing $\mathrm{F}^{131}$-labeled $\mathrm{T}_{4}$ in $0.05 \mathrm{M}$ phosphate, standard Tris-maleate, and $0.05 \mathrm{M}$ barbital buffers were dialyzed for 48 hours against 12 -ml samples of 5 per cent HSA previously equilibrated by dialysis against the corresponding buffer systems. Rates of dialysis of TCA-precipitable radioactivity were then assessed. With the rate of dialysis in phosphate buffer as a reference $(0.047$ per cent per 24 hours), rates of dialysis in duplicate experiments averaged: phosphate, 1.00; Tris-maleate, 0.96; and barbital, 8.20. At the completion of dialysis, the specific radioactivity of prealbumin in Tris buffer, in counts per minute per milligrams protein, was more than 2,500 times that of the albumin with which it had been equilibrated. In barbital buffer, the ratio of prealbumin to albumin specific activity was greatly reduced, but remained in excess of 300 .

In view of reports that salicylates accelerate both the peripheral turnover of $\mathrm{T}_{4}$ in vivo (10) and the rate of dialysis of $T_{4}$ from serum in vitro (11), experiments were performed to assess whether salicylate ion produced these effects by inhibiting the association of $T_{4}$ with either TBG or TBPA. Since it seemed possible that any bond between salicylate and a $T_{4}$-binding protein might be so weak as to be disrupted by either the dilution of salicylate or by the electromotive forces incident to electrophoresis, experiments were performed using Tris-maleate buffer enriched with salicylate at $\mathrm{pH} 8.6$ to a concentration of $30 \mathrm{mg}$ per $100 \mathrm{ml}$. This concentration of salicylate is similar to that achieved in serum by large therapeutic doses in vivo (10) and to that employed in the dialysis experiments reported by others (11). A typical result, comparing $\mathrm{T}_{4}$-binding in standard Tris-maleate buffer to that obtained in Trismaleate-salicylate, is shown in Figure 10 . Salicylate induced a pronounced inhibition of $T_{4}$ binding by TBPA. As had been the case with barbital, this effect was associated with a distinct increase in the $\mathrm{T}_{4}$-binding capacity of moieties in the $\alpha$-globulin zone. 


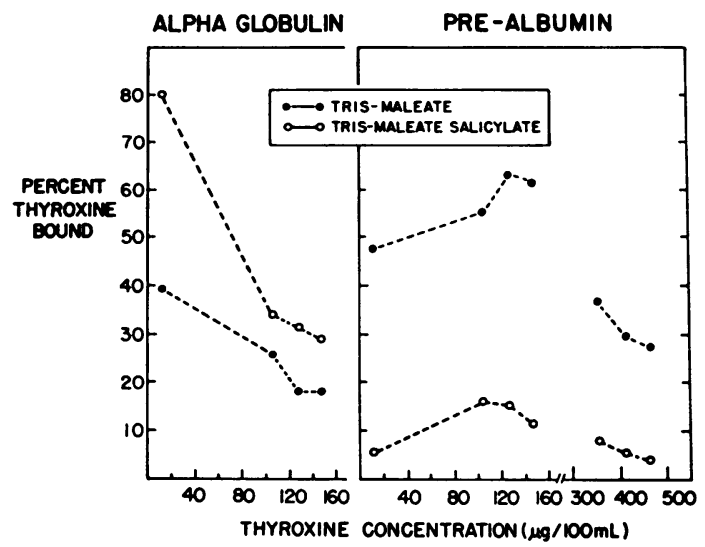

Fig. 10. The efFect of AdDing SAlicylate (30 Mg PER $100 \mathrm{ML}$ ) to Tris-maleate BUfFer, PH 8.6, ON THE BINDING OF THYROXINE TO PROTEINS IN THE $\alpha$-GLOBULIN AND PREALBUMIN ZONES OF NORMAL HUMAN SERLM.

Similar though less striking inhibition of $\mathrm{T}_{4}{ }^{-}$ binding by TBPA was induced by enriching serum with $30 \mathrm{mg}$ salicylate per $100 \mathrm{ml}$ before electrophoresis in standard Tris-maleate buffer.

Since electrophoretic experiments were performed at $\mathrm{pH} 8.6$, dialysis experiments were performed to obtain further evidence concerning the locus of inhibition of $\mathrm{T}_{4}$-binding induced by salicylates at physiological $\mathrm{pH}$. Advantage was taken of observations (see above) which indicated that, unlike $\mathrm{L}-\mathrm{T}_{4}, \mathrm{D}-\mathrm{T}_{4}$ is firmly bound by $\mathrm{TBG}$, but is bound little if at all by TBPA. To normal serum was added one-tenth part of $0.5 \mathrm{M}$ phosphate buffer at $\mathrm{pH} 7.4$. A $2.0-\mathrm{ml}$ sample of this mixture was enriched with stable $\mathrm{L}_{-} \mathrm{T}_{4}$ and $\mathrm{I}^{131}$ labeled L- or $\mathrm{D}-\mathrm{T}_{4}$ to a total concentration of 50 to $55 \mu \mathrm{g}$ per $100 \mathrm{ml}$. This was dialyzed against 12 $\mathrm{ml}$ of the same serum-buffer mixture containing an equivalent concentration of stable $\mathrm{L}_{-} \mathrm{T}_{4}$. Additional vessels were prepared in which the serum both within and outside of the dialysis sacs were enriched with salicylate $(50 \mathrm{mg}$ per $100 \mathrm{ml}, \mathrm{pH}$ 7.4). Vessels were placed on a rocking platform in a cold room at $4^{\circ} \mathrm{C}$. Dialyzed samples were withdrawn periodically for 48 hours and TCAprecipitable radioactivity determined. As shown in Figure 11, $\mathrm{L}-\mathrm{T}_{4}$ was dialyzed from serum less rapidly than $\mathrm{D}-\mathrm{T}_{4}$. The rate of dialysis of $\mathrm{L}-\mathrm{T}_{4}$, however, was greatly increased by salicylate, whereas that of $\mathrm{D}-\mathrm{T}_{4}$ increased only slightly. Electrophoretic studies of the contents of the dialysis sacs revealed that none of the radioactivity introduced with the labeled $\mathrm{D}-\mathrm{T}_{4}$ was associated with TBPA in samples either containing or devoid of salicylate.

Barbital, $0.05 \mathrm{M}$ at $\mathrm{pH}$ 7.4, when added to serum, produced the same relative effects on the rate of dialysis of $\mathrm{D}-$ and $\mathrm{L}-\mathrm{T}_{4}$ as did salicylate. When, however, salicylate was added in addition to barbital, no further increase in the rates of dialysis of the two isomers of $\mathrm{T}_{4}$ occurred.

When comparable experiments were performed in a serum virtually devoid of TBG but with a normal binding activity of TBPA, L-T 4 was dialyzed from the serum more rapidly than normal, and salicylate greatly increased the rate. The rate of dialysis of $\mathrm{D}-\mathrm{T}_{4}$ in control sacs was as great as that of $\mathrm{L}-\mathrm{T}_{4}$ in the presence of salicylate; it was not further increased by salicylate.

Trypan blue has been reported to increase the uptake of $\mathrm{I}^{131}$-labeled $\mathrm{T}_{4}$ by erythrocytes suspended in serum diluted with buffer at physiological $\mathrm{pH}$ (12). Trypan blue had no effect when erythrocytes were suspended in buffer alone. This finding suggested that trypan blue might interfere with hormonal binding by one or more serum proteins. Samples of a pool of normal human serum were therefore enriched with trypan blue in concentrations of 50,5 , and $0.5 \mathrm{mg}$ per $\mathrm{ml}$. The highest concentration of trypan blue employed was that calculated to yield approximately the same concentration ratio trypan blue to protein as that achieved in the earlier experiments with erythrocytes (12). Portions of these samples

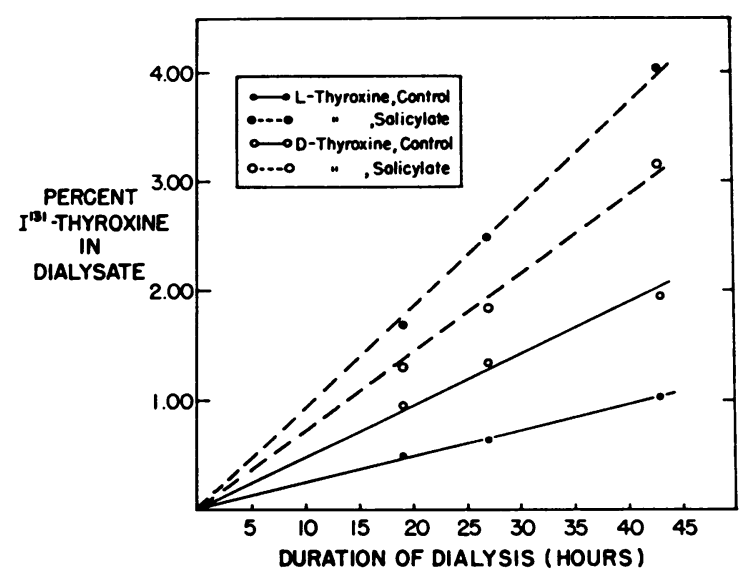

Fig. 11. The efFect of SAlicylate (50 Mg PER 100 ML) ON THE RATE OF DIALYSIS OF I $^{131}$-LABELED L- AND D-THYROXINE FROM NORMAL HUMAN SERUM BUFFERED TO PH 7.4. 
were then enriched with ${ }^{131}$-labeled $\mathrm{T}_{4}$ and with concentrations of stable $T_{4}$ ranging between 87 and $450 \mu \mathrm{g}$ per $100 \mathrm{ml}$; binding capacities of TBG and TBPA were determined by electrophoresis in Tris-maleate buffer. At the highest concentrations of trypan blue employed, partial coagulation of proteins was noted; the electrophoretic pattern of serum proteins was distorted, with a preponderance remaining at the origin and a tail developing anodally. Identification of the usual electrophoretic zones was difficult, but a probable albumin zone was seen (Figure 12). A small proportion of labeled $\mathrm{T}_{4}$ was localized anodally to this region. At the two lower concentrations of trypan blue, some protein remained at the point of application, but the usual electrophoretically separable groups of proteins were nevertheless clearly defined. Trypan blue in concentrations of 5 and $0.5 \mathrm{mg}$ per $100 \mathrm{ml}$ decreased the $\mathrm{T}_{4}$-binding capacity of proteins in the prealbumin zone by an average of 80 per cent and 58 per cent, respectively. A slight increase in the $\mathrm{T}_{4}$-binding capacity of moieties in the $\alpha$-globulin zone was also noted.

Effect of $p H$ on binding. As has recently been reported $(13,14)$, essentially no binding of labeled $\mathrm{T}_{4}$ was noted in the area anodal to albumin when normal serum was subjected to filter paper electrophoresis in Tris-maleate buffer at $\mathrm{pH}$ 7.4.

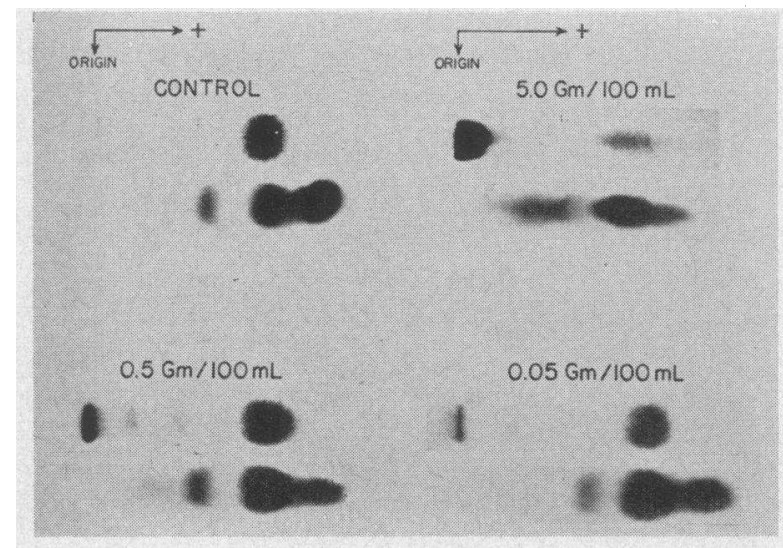

Fig. 12. THE EFFECT OF TRYPAN BLUE ON THE ELECTROPHORETIC MOBILITY OF THE PROTEINS AND THYROXINEBINDING OF NORMAL HUMAN SERUM. Electrophoresis in Tris-maleate buffer, $\mathrm{pH}$ 8.6. Upper strip in each pair represents bromphenol blue stain of electrophoretogram and lower strip represents radioautograph of electrophoretogram before staining. Numbers indicate concentration of trypan blue in serum. For samples shown, stable thyroxine added to a concentration of $87 \mu \mathrm{g}$ per $100 \mathrm{ml}$.
When resin eluates containing sufficient prealbumin and TBG to provide visible spots after bromphenol blue staining were studied by paper electrophoresis at $\mathrm{pH}$ 7.4, prealbumin retained its localization anodal to albumin. Binding of $T_{4}$ was localized, however, entirely to the TBG zone.

In electrophoretic studies performed at $\mathrm{pH} 7.4$, $\mathrm{I}^{131}$-labeled $\mathrm{TA}_{4}$ added to normal serum in tracer concentrations of $0.4 \mu \mathrm{g}$ per $100 \mathrm{ml}$ was bound mainly to TBPA (75 per cent) and also to albumin (24 per cent). When the same samples of serum were studied in buffer at $\mathrm{pH} 8.6, \mathrm{TA}_{4}$ was bound almost entirely ( $>95$ per cent) to TBPA.

Dialysis experiments were performed in which $2 \mathrm{ml}$ of a purified prealbumin solution, at $50 \mathrm{mg}$ per $100 \mathrm{ml}$ and containing tracer quantities of $\mathrm{I}^{131}$-labeled $\mathrm{T}_{4}$, was dialyzed against $12 \mathrm{ml}$ of a $5.0 \mathrm{~g}$ per $100 \mathrm{ml}$ solution of HSA. Rates of dialysis of TCA-precipitable radioactivity were ascertained for solutions prepared in Tris-maleate buffer, $\mathrm{pH} 8.6$ and $\mathrm{pH}$ 7.4. These averaged 0.054 and 0.160 per 24 hours, respectively. After 72 hours of dialysis, the specific activity of prealbumin, in counts per minute per milligrams protein, was 1,120 times as great as that of albumin at $\mathrm{pH}$ 8.6. Although the relative $\mathrm{T}_{4}$-binding activity of prealbumin was decreased at $\mathrm{pH} 7.4$, the specific activity of prealbumin averaged 390 times that of albumin.

Electrophoretic experiments were also performed in an agar gel system $(15,16)$. Normal sera and solutions of HSA, both containing $\mathrm{I}^{131}$ labeled $T_{4}$, were subjected to electrophoresis on glass slides in a film of agar gel $(1.0 \mathrm{~g}$ per $100 \mathrm{ml})$,

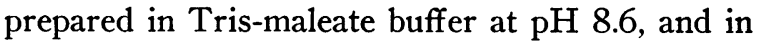
$0.05 \mathrm{M}$ phosphate buffer at $\mathrm{pH}$ 7.4. After electrophoresis, slides were placed in apposition to no-screen X-ray film and radioautographs were prepared. No attempt was made to quantify the distribution of radioactivity among the various protein zones. Nevertheless, during electrophoresis of serum both at $\mathrm{pH} 7.4$ and at 8.6, distinct binding of $\mathrm{T}_{4}$ to TBPA, as well as to TBG and albumin, was clearly evident (Figure 13). The density of radioautographic darkening in the TBPA zone appeared greater at $\mathrm{pH} 8.6$ than at 7.4.

Additional electrophoretic experiments were carried out in filter paper with $0.06 \mathrm{M}$ phosphate 


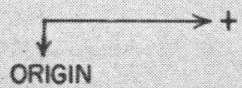

$3 \%$ SERUM ALBUMIN

NORMAL SERUM

Binding characteristics of prealbumin in cerebrospinal fluid. Pooled human cerebrospinal fluid was subjected to pressure dialysis against large volumes of distilled water. After lyophilization, proteins were dissolved in physiological saline solution to a concentration of $4.0 \mathrm{~g}$ per $100 \mathrm{ml}$. Solutions were enriched with tracer quantities of labeled $\mathrm{T}_{4}$ or $\mathrm{T}_{3}$, and were subjected to electrophoresis in standard Tris-maleate buffer and in the same buffer to which either $0.05 \mathrm{M}$ barbital or $30 \mathrm{mg}$ per $100 \mathrm{ml}$ salicylate had been added. In all buffer systems, a faintly discernible bromphenol blue spot was noted in the prealbumin zone. In Tris-maleate buffer, $T_{4}$ was localized almost entirely in this area, but small proportions were associated with the albumin and $\alpha$-globulin zones. $\mathrm{T}_{3}$ was not localized in the prealbumin zone, was principally associated with albumin, and trailed cathodally toward the point of application. Addition of barbital or of salicylate diminished, but did not entirely inhibit, binding of $T_{4}$ in the prealbumin zone. $\mathrm{T}_{4}$ displaced from prealbumin was bound mainly to albumin, but small proportions were also localized in the $\alpha$ - and $\beta$-globulin zones.

\section{DISCUSSION}

Since the discovery of TBG in 1952, a diversity of views has been held at one time or another concerning the number, nature, and role of the the proteins in plasma that bind $T_{4}$. These diverse views can perhaps be ascribed to possible artifacts introduced by available methods for studying the binding of $\mathrm{T}_{4}$ to specific proteins. By exposing the interactants to electrical forces, to various supporting media, and to unphysiological conditions of ionic strength, composition, and $\mathrm{pH}$, the zonal electrophoretic techniques almost always employed in studies of this subject may distort the protein-hormone interactions that obtain in vivo. As a result, findings in no single system can be considered as absolute, and conclusions are best drawn, as the present studies have attempted, from a correlation of findings obtained under a variety of experimental conditions and in several different systems.

Aside from TBG, the protein that has received greatest attention as a mediator in the transport of $T_{t}$ is one termed the thyroxine-binding prealbumin. TBPA. Consistent demonstration of 
TBPA in normal human serum first came as the result of substituting, in a conventional filterpaper electrophoretic system at $\mathrm{pH} 8.6$, Trismaleate buffer for the barbital buffer almost universally employed in studies of $\mathrm{T}_{4}$-binding to that time (3). It was suggested that TBPA and TBG are distinct proteins, sharing a significant role in the transport of $T_{4}$. Since then, however, various doubts concerning the nature and physiological import of TBPA have been expressed. The present report represents a compilation of observations supporting the initial view that TBPA is distinct from TBG and participates significantly in the transport of $T_{4}$

Since a number of the present observations concern the $\mathrm{T}_{4}$-binding properties of a purified prealbumin, it is first necessary to consider whether this protein is identical with TBPA. Although a number of proteins have been noted that migrate rapidly toward the anode during electrophoresis of serum (17-19), the findings of Blumberg and Robbins (20) in the starch gel system indicate that in human serum, only the most rapidly migrating prealbumin, prealbumin 1 of Smithies (18) or A of Poulik and Smithies (19), binds $\mathrm{T}_{4}$. The purified prealbumin described by Schultze, Schönenberger, and Schwick (21), shown by Tata to bind $\mathrm{T}_{4}$ avidly (22), also appears to migrate to the position of prealbumin 1 in the starch gel system (23). The immunologic identity of the prealbumin of Schultze and co-workers with the $\mathrm{T}_{4}$-binding prealbumin of cerebrospinal fluid and of whole serum has also been claimed (24). It is therefore relevant that, in the present studies, at least several properties were shared by the TBPA of serum, of cerebrospinal fluid, and the present preparation of purified prealbumin. All had similar electrophoretic mobility and strongly bound $T_{4}$, but not $T_{3}$. In all, the binding of $T_{4}$ was inhibited by barbital and by salicylate. These findings suggest that the $\mathrm{T}_{4}$-binding moieties in all are either the same or very similar. Since starch gel electrophoresis of the present preparation of prealbumin has not been performed, it is not certain whether this preparation contains prealbumins other than those found in prealbumin 1 . Nevertheless, it seems likely that TBPA is, if not the sole component of the present preparation of prealbumin, the major protein responsible for its $\mathrm{T}_{4}$-binding properties.
The relation of Tris to the binding of $T_{4}$ by $T B P A$. Certain observations have suggested that the ability of TBPA to bind $\mathrm{T}_{4}$ depends upon an interaction of the protein or hormone with Tris (25). It has been reported that when samples of TBPA, prepared by elution from starch gels after electrophoresis of serum in Tris buffer, were dialyzed free of Tris, their $\mathrm{T}_{4}$-binding potency was lost. When the Tris was replaced, $\mathrm{T}_{4^{-}}$ binding was restored, as shown by the ability of such preparations once again to inhibit the in vitro uptake of labeled $\mathrm{T}_{4}$ by red blood cells. The uptake of labeled $\mathrm{T}_{4}$ by red blood cells from whole plasma was also decreased when Tris was added. Since this report contained no data concerning the effects of Tris on the uptake of $T_{4}$ by red blood cells from protein-free media, the findings are difficult to interpret. In any event, the data seem inconsistent with the present or previous observations that $a$ ) the $\mathrm{T}_{4}$-binding capacity of TBPA does not vary significantly with wide variations in the concentration of Tris-maleate buffer employed, $b$ ) preparations of purified prealbumin failed to lose significant quantities of labeled $\mathrm{T}_{4}$ when dialyzed extensively against distilled water, c) Tris-maleate, when compared with several other buffer systems, did not alter significantly the rate of dialysis of labeled $\mathrm{T}_{4}$ from solutions of purified prealbumin, and $d$ ) TBPA is readily demonstrable at $\mathrm{pH} 8.6$ when buffers other than Tris but containing no barbital are employed in the electrophoresis of serum (26-28). Furthermore, binding of $\mathrm{T}_{4}$ by TBPA is readily demonstrable in normal serum when electrophoresis is performed in a barbital buffer more dilute than usual $(27,29)$. Finally, as assessed by both electrophoretic and dialysis systems at $\mathrm{pH}$ 8.6, purified prealbumin displayed a binding potency far greater than that of albumin, even in the usual $0.05 \mathrm{M}$ barbital buffer. These findings clearly indicate that the ability of prealbumin to bind $\mathrm{T}_{4}$ avidly is not an artifact specifically induced by the Tris-maleate buffer system.

The effects of binding inhibitors. The foregoing observations indicate that the indemonstrability of TBPA during studies performed in normally constituted barbital buffer, rather than its demonstration during the use of other buffers, represents an artifactual situation. The present observations strongly support the initial hypothe- 
sis that this artifact follows from the inhibition by barbital of the binding of $T_{4}$ by TBPA (3). Thus. although barbital is thought to inhibit the binding of $T_{+}$by HSA (25), it greatly increased the rate of passage of labeled $\mathrm{T}_{+}$across a dialysis membrane from purified prealbumin to HSA. Furthermore, when added to Tris-maleate buffer in increasing concentrations, barbital progressively decreased $\mathrm{T}_{4}$-binding by TBPA in serum; at the usual $0.05 \mathrm{M}$ barbital concentration binding of $\mathrm{T}_{+}$ was completely abolished. In contrast. comparable concentrations of barbital diminished, but did not abolish, the binding by TBPA of $\mathrm{TA}_{4}$, a compound herein shown to be more avidly bound by TBPA than is $T_{+}$itself. These findings are consonant with the interpretation that barbital and $\mathrm{T}_{4}$ (and $\mathrm{TA}_{4}$ ) compete for common binding sites on the TBPA molecule. This competition need not result, however, in a complete loss of the $T_{+}$binding ability of prealbumin, as shown by the present electrophoretic and dialysis experiments, by previous studies of cerebrospinal fluid and of the serum of patients with nephrosis (30), and by studies of normal serum performed in dilute barbital buffer. The quantity or proportion of $T_{t}$ bound by prealloumin in the presence of barbital would appear to depend upon the relative concentration of these interactants and upon the availability of $T_{4}$-binding sites on other proteins within the mixture. Similar considerations would presumably apply in the case of other inhibitors of $\mathrm{T}_{4}$-binding by TBPA, such as trypan blue, salicylate, and dinitrophenol (31).

In the present studies, the inhibition of $\mathrm{T}_{4}$ binding by TBPA induced by addition of barbital. trypan blue, or salicylates to the Tris-maleate buffer was consistently associated with an increase in the $\mathrm{T}_{4}$-binding capacity of proteins migrating in the $\alpha$-globulin zone. The two-dimensional electrophoretic observations of Blumberg and his coworkers would suggest that barbital may cause a portion of the TBPA in serum to migrate in the $\alpha$-globulin zone. In the present studies, radioautographs of sera that had undergone electrophoresis in Tris-maleate-barbital buffer did reveal a faint band of radioactivity in the $\alpha$-globulin zone. but this did not appear sufficient to account for the increased $\alpha$-globulin binding of $\mathrm{T}_{4}$ that barbital induces. Furthermore, it seems unlikely that the electrophoretic mobility of more than a small fraction of TBPA could be altered by barbital, since both high concentrations of purified prealbumin and the protein in serum that binds $\mathrm{TA}_{4}$ (presumably TBPA) retain their characteristic migration during electrophoresis in barbital buffer. It is, in addition, highly improbable that any TBPA whose mobility might be altered by barbital would continue to bind $T_{t}$ when $T_{4}$ binding by the remainder of the TBPA is completely inhibited by this agent. Thus, it is not clear why barbital increases $\mathrm{T}_{4}$-binding in the $\alpha$-globulin zone, although this effect may depend on the presence of TBG, since no appreciable increase was induced by barbital in a serum virtually devoid of TBG but normal with respect to TBPA.

The differing properties of TBG and TBPA. In 1958. Tata, on the basis of both immunologic and electrophoretic observations. suggested that TBPA is the principal $\mathrm{T}_{4}$-binding moiety of serum, but that in its natural state, TBPA is bound in a complex to an $\alpha$-globulin, giving rise to TBG (32). A previous communication from this laboratory pointed out the difficulties in interpreting the observations upon which this hypothesis had been based (4). Chief among these is the fact that all electrophoretic experiments had been performed in barbital buffer. Major functional differences between TBG and TBPA that rendered this hypothesis unlikely were also cited at that time and have been described in detail here. Among these is the differing affinity of the two proteins for several derivatives of $T_{4}$. Thus, $T_{:}$: is not bound by TBPA to a detectable degree (3). $\mathrm{TA}_{4}$ and $\mathrm{TP}_{4}$ are very firmly bound by TBPA. whereas $\mathrm{TA}_{3}$ and $\mathrm{TP}_{3}$ are bound progressively less well. On the other hand, TBG binds none of these deaminated derivatives to a significant extent. With regard to $\mathrm{TA}_{4}$ and $\mathrm{TP}_{4}$, the present findings agree with those of Tanaka and Starr (33). These authors, however, failed to note appreciable binding of $\mathrm{TA}_{3}$ and $\mathrm{TP}_{3}$ to TBPA, probably because electrophoretic studies of these less intensely bound compounds were performed in the inhibitory barbital buffer. ${ }^{8}$ In general, the relative in-

8 Tata, Widnell, and Gratzer have suggested that there exist in TBPA two varieties of binding sites, one of which binds $T_{4}$ and $\mathrm{TA}_{4}$ and is inhibited by barbital, the other of which binds $\mathrm{TA}_{4}$ but not $\mathrm{T}_{4}$, and is not inhibited by barbital (34). Both these observations and those presently described, however, are equally consistent 
tensity of the bond between TBPA and either $T_{4}$ or its derivatives, as herein described, bears a close inverse correlation with the rate of dialysis of these compounds from serum and with values for their in zitro uptake from plasma by erythrocytes (35).

A further striking difference between TBG and TBPA lies in their affinities for $\mathrm{D}-\mathrm{T}_{+}$. The present observations indicate that the binding of $\mathrm{D}-\mathrm{T}_{4}$ to $\mathrm{TBG}$ is at least as intense as that of $\mathrm{L}-\mathrm{T}_{+}$. Previous studies of this question have led to conflicting results. Since earlier electrophoretic observations were performed in barbital buffer, no information on the binding of $\mathrm{D}-\mathrm{T}_{+}$to TBPA has been available. Some workers, however, have been led to suggest that $\mathrm{D}-\mathrm{T}_{4}$ is strongly bound by $\mathrm{TBG}(33,36)$, while others have indicated that it is not (37). Tata's observations based on the $\mathrm{T}_{4}$-stabilization method to assess binding indicate that Fraction IV-6 of Cohn and his colleagues binds $\mathrm{D}-\mathrm{T}_{+}$avidly (22). In view of the present observations, this binding cannot be ascribed to the TBPA present in this fraction, but must be attributed to a firm bond between $\mathrm{D}-\mathrm{T}_{+}$and TBG.

The differing responses to binding inhibitors and to changes in $\mathrm{pH}$ described here and elsewhere $(13,14,31)$, as well as the independent variations in the $T_{4}$-binding capacities of $T B G$ and TBPA that occur in diverse abnormal states (38). provide further evidence of the striking functional dissimilarities between the two proteins.

Finally, if TBG were the result of an interaction between TBPA and another serum protein, it would follow from the regularity with which TBPA can be demonstrated in Tris and other buffer systems that such buffers must dissociate the two proteins and liberate free TBPA. This seems unlikely, however, since values for the $T_{4}$-binding capacity of $\mathrm{TBG}$ in serum do not depend upon whether the buffer in which studies are performed does or does not permit the demonstration of TBPA. Furthermore, in the present experiments, fractions highly enriched in TBG and devoid of TBPA were prepared from

with the interpretation that $\mathrm{T}_{4}$ and its derivatives are bound by common binding sites on TBPA, but with varying intensity. The common inhibitor, barbital, would therefore variably affect their binding. Additional evidence bearing upon these possibilities will be discussed in a later communication. other plasma fractions by electrophoresis in barbital buffer. No dissociation of TBPA from TBG could be demonstrated when such preparations were subjected to electrophoresis in a Tris-maleate system.

In view of these many considerations, it is very unlikely that TBPA is the prosthetic group of TBG, as Tata once suggested (32). In more recent publications, Tata has confirmed many of the foregoing findings and has provided additional evidence that leads him now to concur in the opinion that TBG and TBPA are distinct proteins $(34,39)$. Apparently, much of the earlier evidence that led him to the conclusion that TBG and TBPA are closely related was due, as we had suggested (4), to contamination by TBG of the prealbumin that he had employed.

The effects of $p H$ on hormonal binding of $T B P A$. A third question raised concerning the importance of TBPA deals with the ability of the protein to bind $\mathrm{T}_{4}$ at physiological $\mathrm{pH}$. During conventional filter-paper electrophoresis of normal serum at $\mathrm{pH} 7.4$, virtually no binding of $\mathrm{T}_{4}$ by TBPA can be demonstrated $(13,14)$. The present studies indicate that this finding cannot be ascribed to a change in the electrophoretic mo-

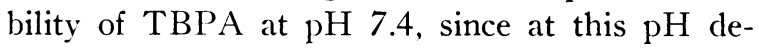
aminated derivatives of $\mathrm{T}_{+}$continue to bind to proteins migrating anodal to albumin, albeit less intensely. Furthermore, in protein fractions or in serum sufficiently enriched with prealbumin to permit determination of its electrophoretic mobility by protein staining, prealbumin at $\mathrm{pH} 7.4$ retains its characteristic location anodal to albumin.

The absence of demonstrable binding of $\mathrm{T}_{4}$ by TBPA during electrophoresis of serum at $\mathrm{pH} 7.4$ might also be explained by the observation that the binding avidity of TBPA is far less intense at $\mathrm{pH}$ 7.4 than at $\mathrm{pH}$ 8.6. Although preallbumin remained far more potent in direct binding competition and on a unit weight basis than albumin at $\mathrm{pH} \mathrm{7.4,} \mathrm{it} \mathrm{might} \mathrm{be} \mathrm{that} \mathrm{the} \mathrm{greater} \mathrm{binding} \mathrm{po-}$ tency of TBG and the far greater concentration of albumin in plasma would make TBPA a negligible factor in the transport of $\mathrm{T}_{+}$in viz'o. Considerable light was shed upon this question by the observation of Hollander, Odak, Prout, and Asper that when electrophoresis of serum at $\mathrm{pH} 7.4$ is carried out in agar gel rather than filter paper, a considerable proportion of labeled $\mathrm{T}_{t}$ is associ- 
ated with TBPA (16). Indeed, in agar gel, these workers noted very little difference between the proportion of labeled $\mathrm{T}_{+}$bound by TBPA at $\mathrm{pH}$ 7.4 and $\mathrm{pH}$ 8.6. The electrophoretic demonstration of TBPA at $\mathrm{pH} 7.4$ in agar gels has been confirmed in the present studies. In addition, data has been obtained that may explain the discrepant findings in the two electrophoretic systems. It seemed possible that the binding activity of TBPA at $\mathrm{pH} 7.4$ is sufficiently reduced so that during its relatively lengthy electrophoretic migration, TBPA gives up its bound $T_{4}$ as a result of a binding competition with filter paper. More slowly migrating proteins, following in the track of TBPA, and migrating less far, would be able to compete for $T_{*}$ with the filter paper, either readsorbing the hormone or appearing to do so because of the radioactive trail left by TBPA. The present experiments in which labeled $T_{+}$was applied to the filter paper at varying distances anodal to the points of application of serum support this hypothetical sequence. Under these conditions, binding of $\mathrm{T}_{4}$ by TBPA at $\mathrm{pH} 7.4$ was readily seen, and the fraction of hormone bound by TBPA did decrease as the distance traversed by the TBPA$\mathrm{T}_{+}$complex lengthened. Furthermore, much of the $T_{+}$remained affixed to the filter paper at its point of application, even when traversed by albumin and TBG. This suggests that $T_{4}$ is strongly bound by filter paper at this $\mathrm{pH}$. Finally, in those samples in which both TBPA and albumin had migrated across the point of application of $T_{4}$, TBPA bound at least 3 to 10 times the amount of $\mathrm{T}_{+}$bound to albumin. Presumably, the $\mathrm{T}_{+}-$ binding affinity of the agar gel is less intense than that of filter paper, and this permits TBPA to be demonstrable at $\mathrm{pH} 7.4$ in the former supporting medium.

The physiological role of TBPA. The direct demonstration that TBPA in serum binds a significant proportion of $\mathrm{T}_{+}$at physiological $\mathrm{pH}$ provides a prerequisite for the suggestion that TBPA plays a role in the transport of the hormone under physiological conditions. Other data support this view. In the case of TBG, general acceptance of its physiological importance is based mainly on a large body of inferential evidence. Thus, in a number of abnormal states, it has been possible to correlate changes in the concentration and rate of turnover of $\mathrm{T}_{4}$ in riz'o with changes in the $\mathrm{T}_{4}-$ binding avidity of whole serum in vitro. These alterations, in turn, can be correlated with changes in the $\mathrm{T}_{4}$-binding activity of TBG, as assessed electrophoretically at $\mathrm{pH}$ 8.6. ${ }^{9} \quad$ Specific instances in which these correlations occur have recently been reviewed $(2,5)$.

In a comparable manner, considerable data support the inference that TBPA contributes significantly to hormonal transport in nonelectrophoretic systems for the assessment of binding, as well as in vivo. Thus, the decreased $\mathrm{T}_{4}$-binding by serum proteins at $\mathrm{pH} 7.4$ that is induced by trypan blue (12) appears to correlate with the present electrophoretic evidence that trypan blue specifically inhibits binding of $\mathrm{T}_{*}$ by TBPA at $\mathrm{pH}$ 8.6.

In vivo, salicylates promptly increase the fractional peripheral turnover of $\mathrm{T}_{4}(10)$. In vitro, they speed the dialysis of labeled hormone from serum buffered at $\mathrm{pH} 7.4$ (11). Although electrophoretic studies in barbital buffer revealed no effect of salicylates on the binding of $\mathrm{T}_{4}$ by $\mathrm{TBG}$ (10), the presently described studies and those of other workers (31) indicate that salicylates inhibit $\mathrm{T}_{4}$-binding by TBPA. This effect is most readily demonstrable when the buffer medium, rather than the serum, is enriched with the inhibitory agent. Despite such evidence that salicylates inhibit $\mathrm{T}_{4}$-binding by TBPA at $\mathrm{pH}$ 8.6. it seemed possible that at $\mathrm{pH} 7.4$ salicylates might inhibit binding of $T_{4}$ by other proteins, perhaps TBG. The present dialysis experiments. however, suggest that it is TBPA, not TBG, whose $\mathrm{T}_{4}$-binding is inhibited at physiological $\mathrm{pH}$. The greater effect of salicylates on the dialysis of $\mathrm{L}$ than of $\mathrm{D}-\mathrm{T}_{4}$ from normal serum, ${ }^{10}$ the enhanced dialysis of $\mathrm{L}-\mathrm{T}_{4}$ induced by salicylates in a serum virtually devoid of TBG, and the failure of salicylates to increased further the dialysis of $\mathrm{L}_{-} \mathrm{T}_{+}$from serum already enriched with barbital are all consonant with this conclusion.

Other data also indicate that changes in the

\footnotetext{
${ }^{9}$ Although it seems likely that changes in the binding activity of TBG under these conditions would also be demonstrable at $\mathrm{pH} 7.4$, studies directed to this point have not been reported.

10 The slight increase in dialysis of $\mathrm{D}-\mathrm{T}_{+}$induced by salicylates in the experiments shown in Figure 11 can probably be ascribed to displacement of $\mathrm{D}-\mathrm{T}_{4}$ from $\mathrm{TBG}$ by the $\mathrm{L}_{-} \mathrm{T}_{4}$ released by salicylate from TBPA.
} 
binding of $\mathrm{T}_{4}$ by TBPA, as measured at $\mathrm{pH} 8.6$, are associated with alterations in the total binding of $\mathrm{T}_{4}$ in serum at physiological $\mathrm{pH}$. The decrease in electrophoretically demonstrable binding of $\mathrm{T}_{4}$ by TBPA that occurs in the serum of some patients with acute or chronic illness is closely correlated with an increase in the in vitro uptake from such sera of labeled $T_{4}$ and $T_{3}$ by red blood cells (38). Dowling, Hutchinson, Hindle, and Kleeman have. furthermore, reported that a decrease in $T_{4}$-binding by TBPA in the serum of patients with the complications of pregnancy is associated with a greater rate of dialysis of labeled $\mathrm{T}_{+}$from such sera than from the serum of normally pregnant women (40). Finally, since dinitrophenol accelerates the in vivo turnover (41) and in vitro dialysis of $T_{4}(11)$, recent experiments indicating that this agent specifically inhibits the binding activity of TBPA at $\mathrm{pH} 8.6$ (31) and at $\mathrm{pH} 7.4$ (42) provide yet another indication that this protein participates in the transport of $\mathrm{T}_{4}$ in vivo.

Altogether, the observations described or cited herein may be considered to indicate that TBG and TBPA are the major mediators of $T_{+}$transport in normal serum; albumin would appear to contribute little. The relative importance of TBG and TBPA in the regulation of $\mathrm{T}_{+}$metabolism, however, cannot be assessed with certainty. Most observations indicate that TBG is responsible for binding considerably more $T_{+}$than is TBPA. Thus, in the static sense. TBG would be the major protein determinant of the proportion and concentration of free or unbound $\mathrm{T}_{4}$ in plasma. Accordingly it would follow, as is indeed the case, that changes in the binding activity of TBG would be associated with alterations in the fractional turnover of $\mathrm{T}_{4}$ in vivo, and secondarily, with changes in the concentration of hormone in the plasma. In this sense, TBG would serve as a reservoir of thyroid hormone within the circulation, and the hormone bound to it would be metabolically inert.

The suggestion that TBPA binds only a small fraction of the circulating hormone would be consistent with the finding that decreased hormonal binding by this protein, such as that which occurs in some acutely ill patients (38), is not always associated with appreciable reduction in the con- centration of hormone in the blood. ${ }^{11}$ Nevertheless, it does not necessarily follow that TBPA exerts little influence on the metabolism of $T_{4}$. Among other factors, the relative ease with which TBG and TBPA penetrate to the extracellular fluid and hence to the cell membrane would ultimately determine which protein more profoundly influences hormonal turnover. Furthermore, the weaker binding affinity of TBPA than of TBG may give TBPA a metabolic significance beyond that expected from the proportion of $T_{+}$in the blood that it may actually bind. For example, the lability of $\mathrm{T}_{4}-$ binding by TBPA to decreases in $\mathrm{pH}$ may afford a mechanism for the transcapillary passage of $T_{+}$or for its delivery to areas of increased metabolic expenditure, such as exercising muscle. This concept. which suggests that TBG is the "savings account" and TBPA the "checking account" of thyroxine economy, although speculative at present, would serve both to reconcile the majority of available data and to provide a teleological rationale for the existence in plasma of two major $\mathrm{T}_{4}$-binding proteins.

\section{SUM M ARY}

Electrophoretic and dialysis techniques have been employed to determine the binding properties of the thyroxine-binding prealbumin (TBPA) of human plasma and purified preparations thereof. In normal serum, the thyroxine-binding activity of TBPA and purified prealbumin was demonstrable in a variety of alkaline inorganic and organic buffers, and was neither dependent on the presence nor significantly influenced by the concentration of the buffer, tris(hydroxymethyl)aminomethane (Tris).

Barbital inhibited the binding of thyroxine by both TBPA and purified prealbumin. In $0.05 \mathrm{M}$ barbital, the concentration usually employed in electrophoretic buffer media, thyroxine-binding by TBPA was completely abolished, but purified prealbumin retained a binding avidity far greater

11 Although salicylates and dinitrophenol inhibit binding of $\mathrm{T}_{4}$ by TBPA, their ability to accelerate the peripheral turnover of $T_{+}(10,41)$ and to lower protein-bound iodine $(10,41,43)$ need not result from the alteration in binding, but rather may arise from the hypermetabolism which they induce. Furthermore, both agents are capable of slowing thyroidal release of hormone $(44,45)$, and this, too, would tend to lower protein-bound iodine. 
than that of serum albumin. Barbital inhibited the binding of those derivatives of thyroxine that are also bound by TBPA; the extent of inhibition varied inversely with the intensity of the TBPAderivative interaction.

Electrophoretic observations at $\mathrm{pH} 8.6$ indicated that trypan blue and salicylate also inhibit thyroxine-binding by TBPA, whereas. in the case of salicylates, dialysis experiments indicated that such inhibition also occurs at $\mathrm{pH} 7.4$.

The inhibition of thyroxine-binding by TBPA induced by barbital, trypan blue, and salicylate was accompanied by an unexplained increase in thyroxine-binding by proteins migrating in the $\alpha$-globulin zone.

Striking differences between the affinities of the thyroxine-binding globulin (TBG) and of TBPA for several derivatives of thyroxine have been demonstrated. D-Thyroxine was bound by TBG at least as avidly as L-thyroxine, but was bound little if at all by TBPA. 3,5,3'-L-Triiodothyronine was bound by TBG, but not by TBPA. Deamination of thyroxine and 3.5.3'-L-triiodothyronine yielded compounds whose affinity for TBG was virtually lost, but whose affinity for TBPA was increased. The affinity of TBPA for these derivatives was greater for the tetraiodinated than the triiodinated, and for the acetic acid rather than the propionic acid. analogues.

Previous demonstrations of thyroxine-binding by TBPA during electrophoresis of serum in agar gels at $\mathrm{pH} 7.4$ have been confirmed. Evidence has been presented which suggests that thyroxinebinding by TBPA is not demonstrable during paper electrophoresis at $\mathrm{pH} 7.4$ because of a decreased avidity of TBPA for thyroxine and an increase in the binding of thyroxine by filter paper at this $\mathrm{pH}$.

From these and previous observations, it is concluded that TBPA is a protein native to human plasma and distinct from TBG. Its affinity for thyroxine is not an artifact induced by specific buffers, including Tris. TBPA transports a significant proportion of the thyroxine in plasma at physiological $\mathrm{pH}$, and it may therefore play a special role in the peripheral metabolism of the hormone.

\section{ACKNOWLEDGMENTS}

The author is indebted for valuable technical assistance during portions of this work to Miss Ellen Cavenaugh,
Mrs. Nancy Cramer, and Misses Lillian Eoyang, Patricia Eveleth, Rebecca Feretos, and Cevina Targum.

\section{REFERENCES}

1. Ingbar, S. H., and Freinkel, N. Thyroid hormones in Hormones in Human Plasma, H. N. Antoniades, Ed. Boston, Little, Brown, 1960, p. 515.

2. Robbins, J., and Rall, J. E. Proteins associated with the thyroid hormones. Physiol. Rev. 1960, 40, 415.

3. Ingbar, S. H. Pre-albumin: a thyroxine-binding protein of human plasma. Endocrinology 1958, 63. 256.

4. Ingbar, S. H. The interaction of the thyroid hormones with the proteins of human plasma. Ann. N. Y. Acad. Sci. 1960, 86, 440.

5. Ingbar, S. H., and Freinkel, N. Regulation of the peripheral metabolism of the thyroid hormones. Recent Progr. Hormone Res. 1960, 16, 353.

6. Ingbar, S. H. Clinical and physiological observations in a patient with an idiopathic decrease in the thyroxine-binding globulin of plasma. J. clin. Invest. 1961, 40, 2053.

7. Cohn, E. J., Strong, L. E., Hughes, W. L., Jr., Mulford, D. J., Ashworth, J. N., Melin, M., and Taylor H. L. Preparation and properties of serum and plasma proteins. IV. A system for the separation into fractions of the protein and lipoprotein components of biological tissues and fluids. J. Amer. chem. Soc. 1946, 68, 459.

8. Mehl, J. W. The biuret reaction of proteins in the presence of ethylene glycol. J. biol. Chem. 1945, $157,173$.

9. Porath, J. Methodological studies of zone-electrophoresis in vertical columns. I. Fractionation in cellulose powder columns of substances of low molecular weight exemplified by amino acids and related compounds. Biochim. biophys. Acta (Amst.) 1956, 22, 151.

10. Austen, F. K., Rubini, M. E., Meroney, W. H., and Wolff, J. Salicylates and thyroid function. I. Depression of thyroid function. J. clin. Invest. 1958, 37, 1131.

11. Christensen, L. K. Thyroxine-releasing effect of salicylate and of 2,4-dinitrophenol. Nature (Lond.) 1959, 183, 1189.

12. Crispell, K. R., Coleman, J., and Hyer, H. Factors affecting the binding capacity of human erythrocytes for $\mathrm{I}^{131}$-labeled $l$-thyroxine and $l$-triiadothyronine. J. clin. Endocr. 1957, 17, 1305.

13. Christensen, L. K., and Litonjua, A. D. Is thyroxine binding by prealbumin of physiologic importance? J. clin. Endocr. 1961, 21, 104.

14. Myant, N. B., and Csorio, C. Paper electrophoresis of thyroxine in tris-maleate buffer. J. Physiol. (Lond.) 1960, 152, 601.

15. Bodman, J. Agar gel, starch block, starch gel and sponge rubber electrophoresis in Chromatographic and Electrophoretic Techniques, I. Smith, Ed. New York, Interscience, 1960, vol. 2, p. 91. 
16. Hollander, C. S., Odak, V. V., Prout, T. E., and Asper, S. P., Jr. An evaluation of the role of prealbumin in the binding of thyroxine. J. clin. Endocr. 1962, 22, 617.

17. Hoch, H., and Chanutin, A. Electrophoretic studies on fast moving components of human serum. J. biol. Chem. 1953, 200, 241.

18. Smithies, O. Zone electrophoresis in starch gels. Group variations in the serum proteins of normal human adults. Biochem. J. 1955, 61, 629.

19. Poulik, M. D., and Smithies, O. Comparison and combination of the starch-gel and filter-paper electrophoretic methods applied to human sera: twodimensional electrophoresis. Biochem. J. 1958, 68, 636.

20. Blumberg, B. S., and Robbins, J. Thyroxine-serum protein complexes: single dimension gel and paper electrophoresis studies. Endocrinology 1960, 67, 368.

21. Schultze, H. E., Schönenberger, M., and Schwick, G. Uber ein Präalbumin des menschlichen Serums. Biochem. Z. 1956, 328, 267.

22. Tata, J. R. A new aspect of the interaction between thyroxine and proteins. Biochem. J. 1959, 72, 222.

23. Allison, A. C. Identification of human serum proteins binding iron, copper, and thyroid hormones by starch gel electrophoresis. Experientia 1959, 15, 281.

24. Gavrilesco, K., Courçon, J., Hillion, P., Uriel, J., Lewin, J., and Grabar, P. A study of normal human cerebrospinal fluid by the immuno-electrophoretic method. Nature (Lond.) 1955, 1, 976.

25. Hamolsky, M. W., Fischer, D. B., and Freedberg, A. S. Further studies on the plasma protein-thyroid hormone complex. Endocrinology 1960, 66, 780.

26. Beierwaltes, W. H., and Robbins, J. Familial increase in the thyroxine-binding sites in serum alpha globulin. J. clin. Invest. 1959, 38, 1683.

27. Blumberg, B. S., Farer, L., Rall, J. E., and Robbins, J. Thyroxine-serum protein complexes: two-dimension gel and paper electrophoresis studies. Endocrinology 1961, 68, 25.

28. Sterling, K., and Tabachnick, M. Paper electrophoretic demonstration of thyroxine-binding prealbumin fraction in serum. Endocrinology 1961, 68, 1073.

29. Andreoli, M., and Andreani, D. L'elettroforesi continua applicata allo studio degli ormoni iodati radioattivi. Minerva nucl. 1959, 3, 161.

30. Robbins, J., and Rall, J. E. The interaction of thyroid hormones and protein in biological fluids. Recent Progr. Hormone Res. 1957, 13, 161.
31. Wolff, J., Standaert, M. E., and Rall, J. E. Thyroxine displacement from serum proteins and depression of serum protein-bound iodine by certain drugs. J. clin. Invest. 1961, 40, 1373.

32. Tata, J. R. Prealbumin as a complex in the $\alpha$-globulin fraction in human serum. Nature (Lond.) 1959, 183, 877.

33. Tanaka, S., and Starr, P. The binding of thyroxine analogues by human serum protein. Acta Endocr. (Kbh.) 1959, 31, 161.

34. Tata, J. R., Widnell, C. C., and Gratzer, W. B. A systematic study of factors affecting the binding of thyroxine and related substances to serum proteins. Clin. chim. Acta 1961, 6, 597.

35. Christensen, L. K. The binding to serum protein of acetic and propionic acid analogues of thyroxine and triiodothyronine. Endocrinology 1960, 67, 407.

36. Robbins, J., and Rall, J. E. Effects of triiodothyronine and other thyroxine analogues on thyroxinebinding in human serum. J. clin. Invest. 1955, 34, 1331.

37. Larson, F. C., and Albright, E. C. The specificity of thyroxine binding by serum alpha globulin. Endocrinology 1955, 56, 737.

38. Richards, J. B., Dowling, J. T., and Ingbar, S. H. Alterations in the plasma transport of thyroxine in sick patients and their relation to the abnormality in Graves' disease (abstract). J. clin. Invest. 1959, 38, 1035.

39. Tata, J. R. Nature of thyroxine-binding globulin in human serum. Nature (Lond.) 1961, 189, 573.

40. Dowling, J. T., Hutchinson, D. L., Hindle, W. R., and Kleeman, C. R. Effects of pregnancy on iodine metabolism in the primate. J. clin. Endocr. 1961, 21, 779.

41. Castor, C. W., and Beierwaltes, W. Effect of 2,4dinitrophenol on thyroid function in man. J. clin. Endocr. 1956, 16, 1026.

42. Barakat, R., and Ingbar, S. H. Unpublished observations.

43. Hetzel, B. S., Good, B. F., Wellby, M. L., and Begg, M. W. The effect of salicylate on the plasma protein-bound iodine level in various states of endocrine disorder in man. Aust. Ann. Med. 1962, 11, 34.

44. Wolff, J., and Austen, F. K. Salicylates and thyroid function. II. The effect on the thyroid-pituitary interrelation. J. clin. Invest. 1958, 37, 1144.

45. Hetzel, B. S., Good, B. F., Wellby, M. L., and Charnock, J. S. Salicylate-induced fall in plasma protein-bound iodine in hyperthyroidism. Lancet 1960, $1,957$. 